\title{
ELEMENTAL, PHASE, AND STRUCTURAL ANALYSIS OF GALLSTONES WITH HIATAL HERNIAS IN PATIENTS OF KHARKIV REGION
}

\author{
N.P. Dikiy ${ }^{1 *}$ E.P. Bereznyak ${ }^{1}$, V.V. Boyko ${ }^{2}$, E.P. Medvedeva ${ }^{1}$, \\ K.Yu. Parhomenko ${ }^{3}$, T.A. Parhomenko ${ }^{1}$, Y.S. Hodyreva ${ }^{1}$ \\ ${ }^{1}$ National Science Center "Kharkiv Institute of Physics and Technology", 61108 Kharkiv, Ukraine; \\ ${ }^{2}$ Zaycev V.T. Institute of General and Emergency surgery of the NAMS of Ukraine, 61103 Kharkiv, Ukraine; \\ ${ }^{3}$ Regional Clinical Hospital, 61000 Kharkiv, Ukraine
}

(Received December 30, 2019)

\begin{abstract}
Gamma activation method on linac NSC KIPT, IR-spectrometry and crystal-optical investigations have been used to determinate the content of elements, the phase analysis and structural features of a different organic and inorganic compound in gallstones of patients with hiatal hernia in Kharkiv region. It is shown that it is possible to establish the presence in gallstones of such compounds as bilirubin and its salts, calcium phosphates, calcium carbonate, and different microelements. In the main, the patients of the Kharkiv region have gallstones of mixed type with a combination of cholesterol, calcium carbonate bilirubinate.
\end{abstract}

PACS: $87.64 . \mathrm{km}$

\section{INTRODUCTION}

The pathogenesis of the formation of gallstones in the gallbladder is not yet clearly understood. Approximately $25 \%$ patients in Ukraine require surgical removal [1].

Gallstones consist mainly of organic compounds such as cholesterol, bilirubin, bile acid and fatty acid [2]. Traces elements play a significant role in providing an indication possible mechanism of stone formation [3]. As a rule, gallstones are classified into three categories according to their composition: cholesterol-rich type, pigment-rich bilirubin, and bilirubinate calcium and mixed type out of a combination of cholesterol, calcium carbonate bilirubinate [4]. However, this classification remains unclear and incompletely understood. The study of elemental content and of absorption bands of the major components of gallstones becomes one of the principal problems for contemporary medicine.

In this report, the analysis of different types of gallstones by using the gamma-activation method on linac NSC KIPT, of crystal-optic method and of the IR-spectroscopy method was applied. The method of IR-spectroscopy has a great contribution to the understanding of gallstone composition and is the major tool of choice for the classification of gallstone.

\section{MATERIALS AND METHODS}

Gallstones samples of both sexes were collected extracted from 22 patients during surgery at the Regional Clinical Hospital, Kharkiv. The age group of patients was $38 \ldots 60$ years. These samples were washed many times with distilled water, and then completely dried at room temperature. After drying, gallstone samples were crushed in agate solutions. For IR-spectroscopy analysis, the samples were prepared in the form of transparently compressed tablets from a mixture of $\mathrm{KBr}$, which served as the matrix and the test substance (in the amount of $1 \%$, $100 \mathrm{mg}$ sample). The tablets had a rectangular shape and sizes of $25 \mathrm{x} 5 \mathrm{~mm}$. The pressing pressure was $9200 \mathrm{~kg} / \mathrm{cm}^{2}$. To exclude the absorption bands of the matrix, a tablet of pure potassium bromide, predried at $180^{\circ}$ for 10 hours, was placed in the comparison channel of the device. The powders were ground and mixed in a special closed box; pressing was performed immediately before measuring spectra. The evaluation was carried out on the spectrum of polystyrene with a known frequency of absorption maxima. Correction averaged $10 \ldots 5 \mathrm{~cm}^{-1}$. The IR-spectrometer IRS-29 (LOMO) was used to record absorption spectra in the infrared range. The spectra were recorded in the spectral range $4000 \ldots 400 \mathrm{~cm}^{-1}$ (middle infrared region) [5,6]. Crystal-optical investigations were carried out on POLAM-L211, MIN-8 microscopes with the use of immersion liquids (IZH, OVIZ sets).

The $\gamma$-activation analyses of these samples which were placed in the aluminum container was performed on the LINAC with the energy of $22 \mathrm{MeV}$, following by detection by $\mathrm{Ge}(\mathrm{Li})$-detector with a volume of $50 \mathrm{~cm}^{3}$ with an energy resolution of $3.2 \mathrm{keV}$ in the $1332 \mathrm{keV}$ region $[7,8]$.

\footnotetext{
*Corresponding author E-mail address: ndikiy@kipt.kharkov.ua
} 


\section{RESULTS AND DISCUSSION}

Average concentration elements $(\mathrm{mg} / \mathrm{g})$ in different types of gallstones are presented. It is evident that elements like $\mathrm{Ca}, \mathrm{Mn}, \mathrm{Fe}, \mathrm{Cu}, \mathrm{Zn}, \mathrm{As}, \mathrm{Rb}, \mathrm{Pb}$ commonly present in all types' gallstones. The content $\mathrm{Ca}$ is higher nearly two times in pigment and mixed gallstones as much in cholesterol gallstones.
Ions calcium plays a vital role in metabolic processes. Ions calcium presented in calcium carbonate of mixed gallstones and in calcium billirubinate of pigment gallstones [9]. Average concentration $\mathrm{Mn}$ in pigment gallstones is $\sim(40 \pm 5,0) \mathrm{mg} / \mathrm{g}$ as compared with cholesterol $(5 \pm 0.5) \mathrm{mg} / \mathrm{g}$ and mixed gallstones $(20 \pm 8.2) \mathrm{mg} / \mathrm{g}$. Mn is one of the important microelement and it is a component of numerous enzymes.

Identification of bands in IR-spectra of gallstones

\begin{tabular}{|c|c|c|}
\hline Assignment of band, $\mathrm{cm}^{-1}$ & Combination & Chemical connection \\
\hline 590 & Phosphate Ca & $\mathrm{PO}_{4}^{-3}$ \\
\hline 600 & Cholesterol & $\mathrm{C}=\mathrm{C}$, Stretching $\mathrm{C}-\mathrm{Cl}$ \\
\hline 710 & Aragonite & $\mathrm{CaCO}^{3}(\mathrm{C}-\mathrm{O})$ \\
\hline 730 & Vaterite & $\mathrm{BaCO}^{3}(\mathrm{C}-\mathrm{O})$ \\
\hline 790,830 & Bilirubin & Vibration $(\mathrm{C}-\mathrm{O})$ \\
\hline 796 & Bilirubin & $\mathrm{MgO}$ \\
\hline 870 & Bilirubin & $\mathrm{S}-\mathrm{O}$ \\
\hline 880 & Bilirubin & $\mathrm{CO}_{3}^{-2}$ \\
\hline 920,1020 & Phosphate Ca & $\mathrm{Ca}_{3} \mathrm{PO}_{4}$ \\
\hline 960 & Phosphate Ca & $\mathrm{Ca}_{3} \mathrm{PO}_{4}$ \\
\hline 975,1020 & Bilirubin & Stretching vibration $(\mathrm{C}-\mathrm{C}-\mathrm{H})$ \\
\hline 1050 & Cholesterol & Vibration $(\mathrm{C}-\mathrm{C})$ \\
\hline 1100,1130 & Bilirubin & Bending vibration $(\mathrm{C}-\mathrm{O})$ \\
\hline 1155,1165 & Phosphate Ca & $\mathrm{PO}_{4}^{-3}$ \\
\hline $1166-1020$ & Phosphate Ca & Fucoza, galactoza \\
\hline 1185,1220 & Bilirubin & Vibration $(\mathrm{C}-\mathrm{O})$ and $\nu(\mathrm{C}-\mathrm{N})+\delta(\mathrm{NH})$ \\
\hline 1350 & Cholesterol & Symmetrical bending vibration $\mathrm{CH}_{2}$ \\
\hline 1430 & Vaterite & Stretching vibration $(\mathrm{C}-\mathrm{O})$ \\
\hline 1440 & Vaterite & Stretching vibration $(\mathrm{C}-\mathrm{O})$ \\
\hline $1450-1480$ & Vaterite & $-\mathrm{CH}_{3}$ \\
\hline 1460 & Aragonite & $\mathrm{C}-\mathrm{O}$ \\
\hline $1620,1650,1690$ & Bilirubin & Vibration $(\mathrm{C}=\mathrm{O}, \mathrm{C}=\mathrm{N}, \mathrm{C}=\mathrm{C})$ \\
\hline 2500 & Crystal $\mathrm{H}_{2} \mathrm{O}$ & $\mathrm{O}-\mathrm{H}$ \\
\hline $2850,2870,2880$ & Cholesterol & Stretching symmetrical vibration $(\mathrm{C}-\mathrm{H})$ \\
\hline $2900,2910,2920,2940$ & Cholesterol & Stretching symmetrical vibration $(\mathrm{C}-\mathrm{H})$ \\
\hline $3240 \ldots 3360,3390$ & Bilirubin & Stretching vibration and mode $(\mathrm{OH})$ \\
\hline $3090 \ldots 3510$ & Bilirubin & NH group \\
\hline
\end{tabular}

A comparative analysis of the content of various elements in mixed stones according to our data with the content of elements in pigment and cholesterol stones showed the following picture [3]. Content $\mathrm{Cu}, \mathrm{Zn}$, and $\mathrm{Fe}$ were found to be particularly high in pigment gallstones as cholesterol and mixed gallstones $(2550 \pm 165.0),(154 \pm 74)$, and $(403 \pm 88) \mathrm{mg} / \mathrm{g}$, accordingly). Ions $\mathrm{Cu}$ and $\mathrm{Fe}$ play a significant role in the formation of black pigment. Ions $\mathrm{Cu}$ and $\mathrm{Zn}$ presented in superoxide dismutase enzyme. Moreover, $\mathrm{Zn}$ is antagonist as regards promoters of Fe and $\mathrm{Cu}$ in oxidation-peroxide systems on the level of cell membranes [10]. The content of these trace elements $(\mathrm{Cu}, \mathrm{Zn}$, and $\mathrm{Fe})$ has coincided nearly in cholesterol and mixed gallstones.

The identification of bands in the IR spectra of gallstones is presented in the Table.

The microphotograph of sample gallstones N1 in immersion liquid is shown in Fig.1.

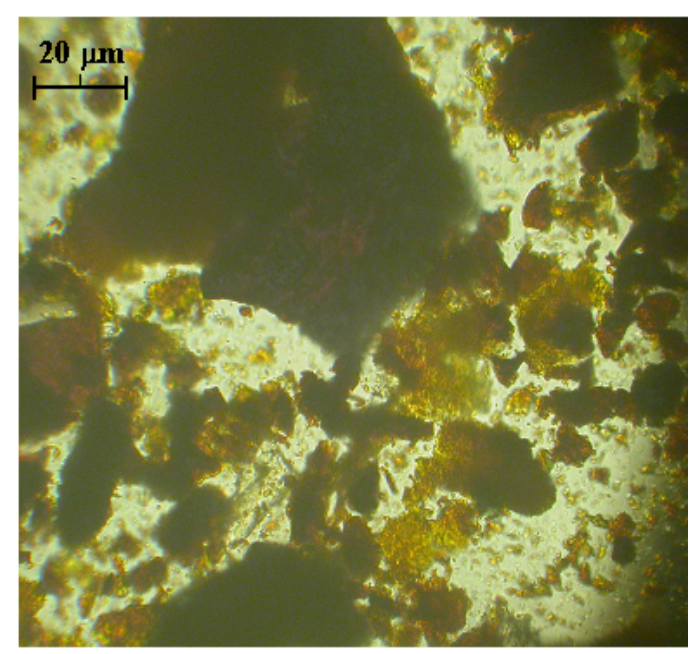

Fig.1. Microphotograph of sample gallstones N1 in immersion liquid in transmitted light. Without analyzer. Mixture two phases: large untransparent fragments and transparent orange-amber poly crystal aggregates 
The content of elements $\mathrm{As}, \mathrm{Rb}, \mathrm{Sr}, \mathrm{Pb}$ was found to be low in cholesterol and mixed type gallstones than in pigment gallstones. Thus, it is shown that gamma activation analyses can be used for determination trace elements in different types of gallstones that are difficult to determine. The composition of gallstones was studied by IR-spectroscopy.
The sample N1 consists of two main phases:

1. fine crystalline aggregates of the amber-orange color of which particles are from 1 to $3 \mu \mathrm{m}$. These particles form aggregates from 5 to $25 \mu \mathrm{m}$;

2. large fragments with incorrect forms have darkbrown color from $30 \ldots 100 \mu \mathrm{m}(\sim 60 \%)$.


Fig.2. IR-absorption spectra the sample gallstones $N 1$

Fig. 2 shows IR-spectra the sample gallstones N1 and $1460 \mathrm{~cm}^{-1}$ ) and small peaks (1100, 1650, and with bands corresponding to different types vibra- $\left.1770 \mathrm{~cm}^{-1}\right)-\mathrm{CaCO}_{3}$. In spectra, there are wide tions of main structural fragments of the organic maximums 600, 1030, 2850, 2910, and $3360 \mathrm{~cm}^{-1}$ compounds with sharp maximums $(710,850,870$, which is characteristic into cholesterol.
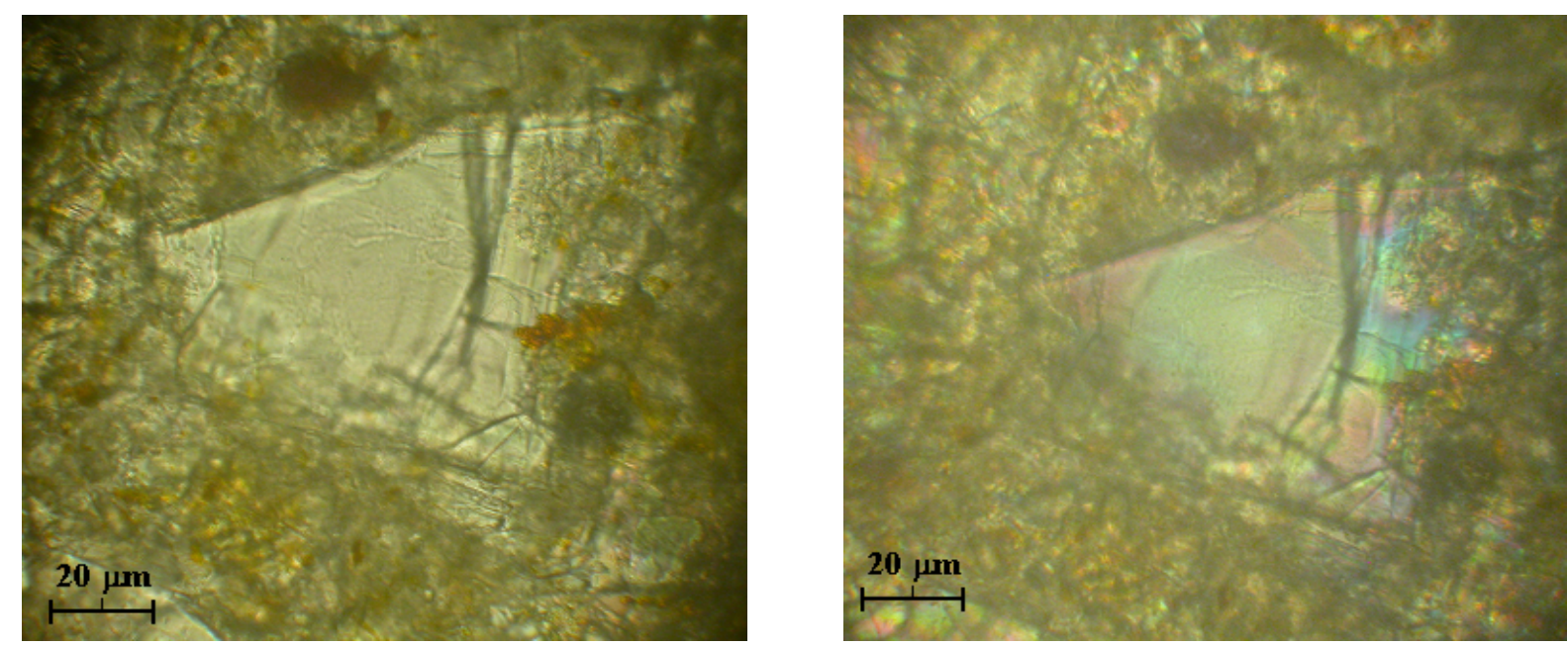

Fig.3. Microphotograph of sample gallstones N2 in immersion liquid in transmitted light. Without analyzer (at left) and with analyzer (at right) 
Figs.3,4 show the microphotograph of sample gallstones N2 in immersion liquid in transmitted light.

The sample N2 is a big gallstone with an ellipse form $\left(\sim 2 \mathrm{x} 1.5 \mathrm{~cm}^{2}\right)$ and a grey-yellow color. The size of the grains is $100 \ldots 120 \mu \mathrm{m}$ (see Fig.3, right) and translucent bright-oranges crystals are $15 \ldots 25 \mu \mathrm{m}$ (see Fig.4).

Fig.5 shows IR-spectra the sample gallstones N2.

The characteristic bands namely 1050, 1350, 2850, 2940 , and $3390 \mathrm{~cm}^{-1}$ are due to cholesterol in pigment gallstones and the second phases have characteristic bands 790, 830, 980,1020, 1100, 1185, 1220, and $1650 \mathrm{~cm}^{-1}$ - due to bilirubin. Besides that, the sample N2 has a specific quantity of ions calcium $\left(\mathrm{Ca}^{2+}\right)$ phosphate $\left(\mathrm{PO}_{4}^{-3}\right)$ (Vaterit).



Fig.4. Microphotograph of sample gallstones N2 in immersion liquid in transmitted light. Without analyzer
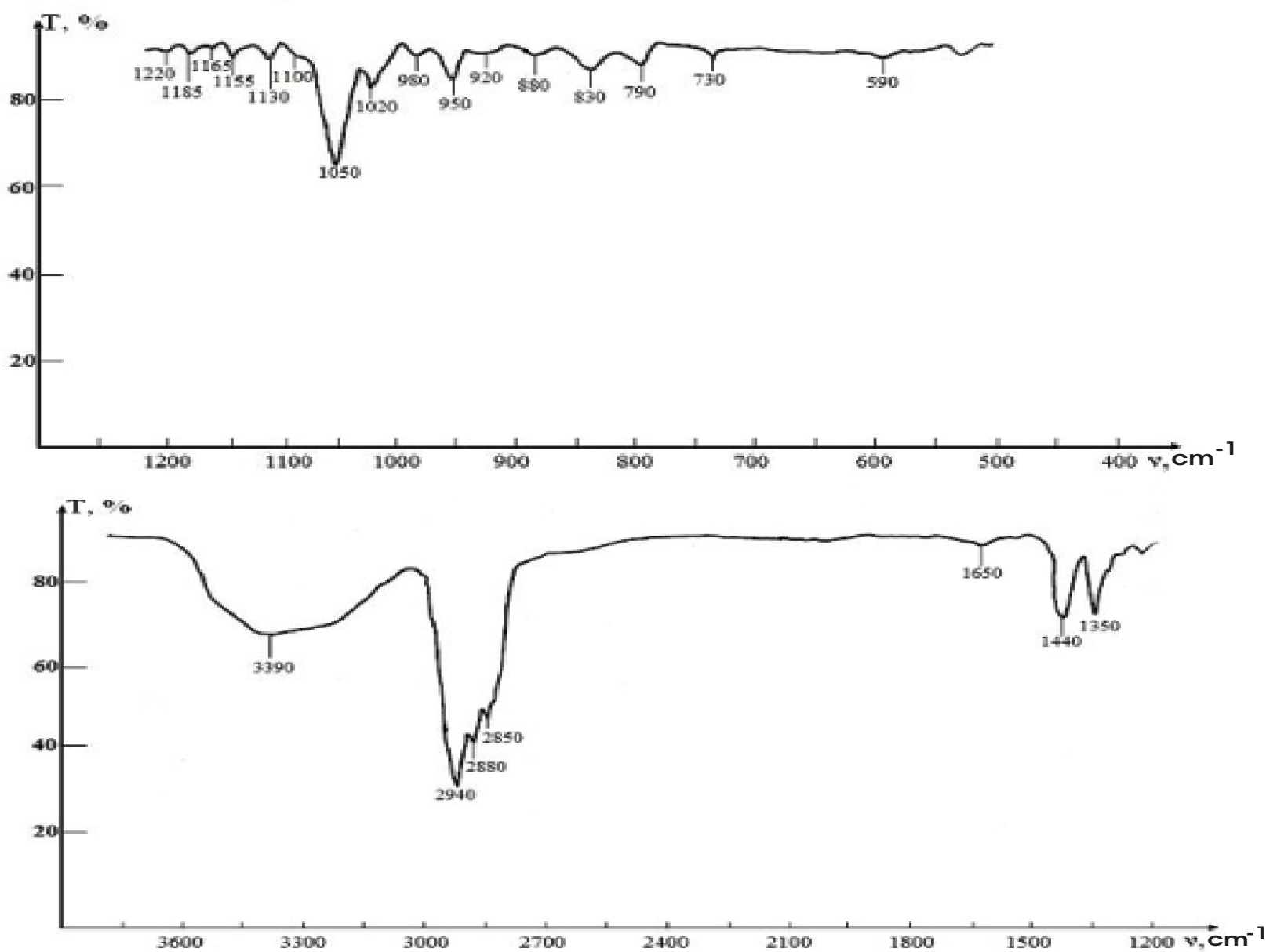

Fig.5. IR-absorption spectra the sample gallstones N2

The sample N3 is polycrystal and amorphous aggregates and has a circular form with a diameter of 4 ...6 $\mathrm{mm}$ and brown-yellow color. The polycrystal aggregates have yellow-orange color dissemination from 10 to $100 \mu \mathrm{m}$ (40\%). The amorphous translucent coagulates have orange-brown color (55\%) and the needle fibers' have grey color [length $=(20 \ldots 25) \mu \mathrm{m}$, width $=(1 \ldots 2) \mu m(\sim 10 \%)]($ Figs.6a, 6b,7).

As shown in Fig. 8 the sample N4 consists of two gallstones $\left(\sim 0.5 \mathrm{x} 0.7 \mathrm{~cm}^{2}\right)$ and had incorrect form and was bright amber in color. These gallstones were single phase, non-transparent and polycrystal mass in the form aggregates. 




Fig.6a. Microphotograph of sample gallstones N3 in immersion liquid in transmitted light. Without analyzer. There are poly crystal aggregates and amorphous translucent coagulates

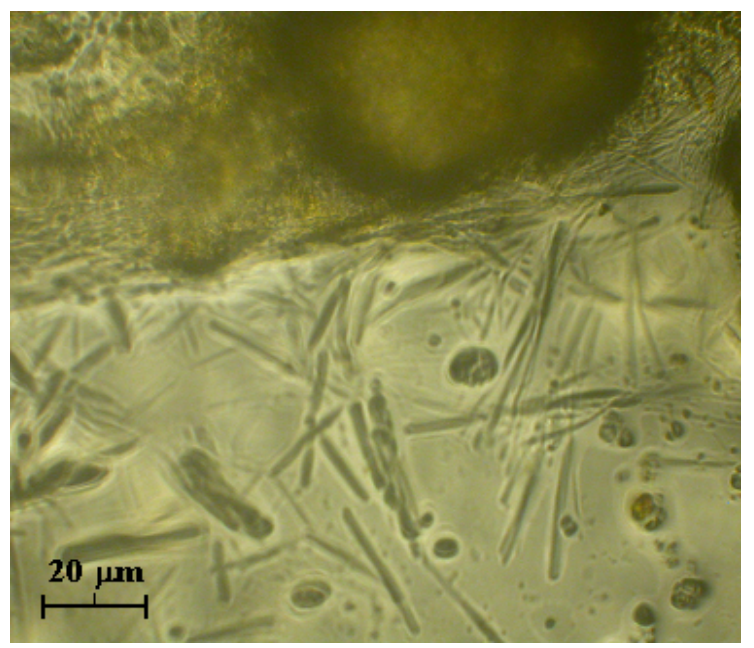

Fig.6b. Microphotograph of sample gallstones N3 in immersion liquid in transmitted light. Without analyzer. There are the needle fibers'
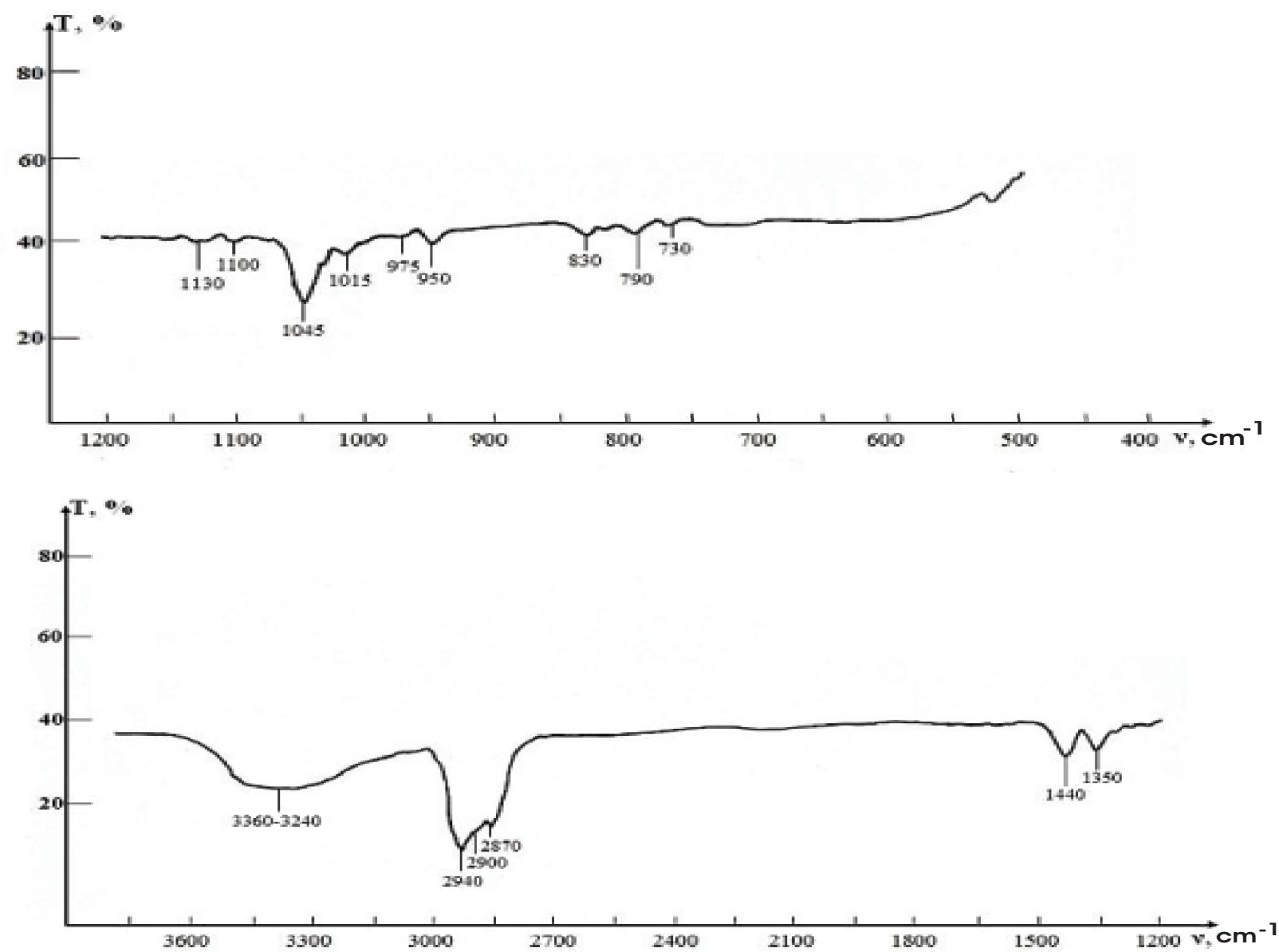

Fig.7. IR-absorption spectra the sample gallstones N3

IR-spectra the sample N4 has low-level transmis- acteristic absorption peaks (615, 1045, 1350, 2850, sion due to bilirubin (55\%) with weak diffuse maxi- 2880, and $2910 \mathrm{~cm}^{-1}$ (Fig.10). The spectrum mum and weak intensity of spectral lines $(790,830$, had the characteristic bilirubin absorption bands $975,1015,1100,1130$, and $\left.3360 \ldots 3240 \mathrm{~cm}^{-1}\right)$. The $(790,830,980,1020,1100,1130,1175,1200$, sample contains crystal cholesterol $\left(1045,1350,2870, \quad 1630\right.$, and $\left.3510 \ldots 3090 \mathrm{~cm}^{-1}\right)$ with less intensive peaks 2900 , and $\left.2940 \mathrm{~cm}^{-1}\right)$ to $40 \%$. There are an insignif- $(25 \ldots 30 \%)$, Vaterit $\left(730,880,1430 \mathrm{~cm}^{-1}\right)$ and calicant quantity of Vaterit and calcium phosphate.

IR-spectrum of crystal cholesterol had the char- (see Fig.10). 


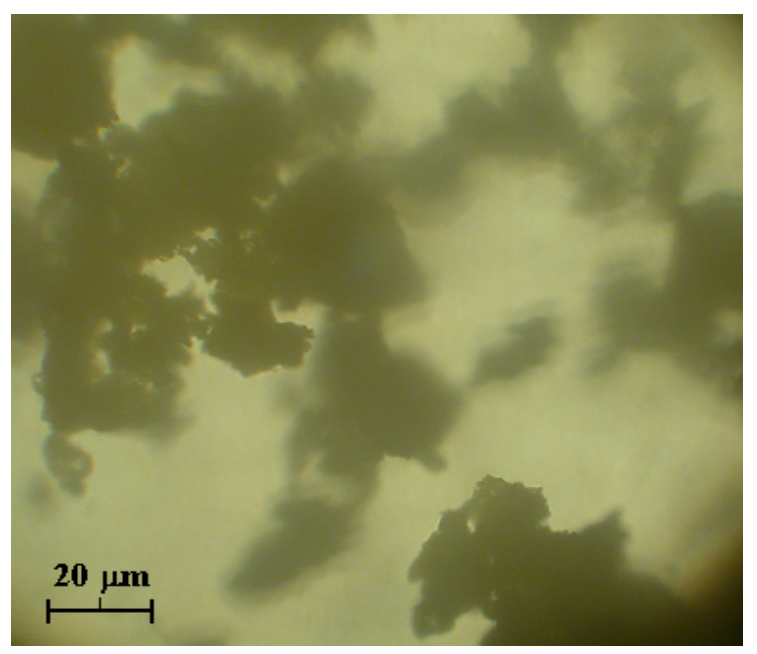

Fig.8. Microphotograph of sample gallstones $N_{4}$ in immersion liquid in transmitted light. Without analyzer. There are non-transparent aggregates

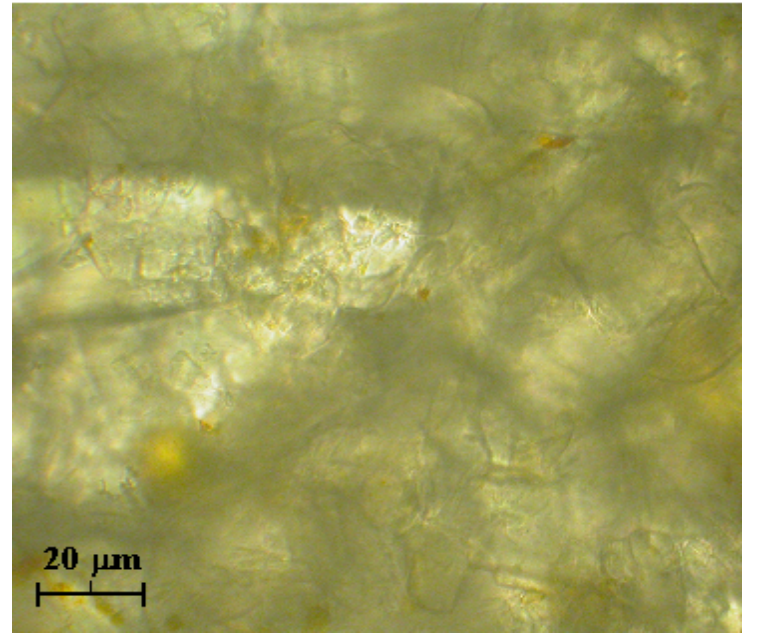

Fig.9. Microphotograph of sample gallstones N5 in immersion liquid in transmitted light. Without analyzer. There are mix crystal phase with prevail grey fine-crystalline mass


Fig.10. IR-absorption spectra the sample gallstones N4

As shown in Fig.9 the sample N5 was the ellipsoidal form with a smooth surface $\left(1.5 \times 1 \mathrm{~cm}^{-1}\right)$ and yellow-grey color.

The sample had a mix crystal phase:

1. Fine-crystalline transparent grey mass $(\sim 70 \%)$;

2. Transparent grains with strong pleochroism $(\sim 20 \%)$;

3. Single transparent grains bright orange color
$(10 \ldots 15 \mu \mathrm{m}),(\sim 10 \%)$.

IR-absorption bands sample N5 is indicating cholesterol $(1050,1350,2850,2890,2920$, and $3390 \mathrm{~cm}^{-1}$ ) (to $70 \%$ ), bilirubin $(975,1100,1130$, $1170,1195,1620$, and $1690 \mathrm{~cm}^{-1}$ ), calcium phosphate $\left(590,920\right.$ and $\left.950 \mathrm{~cm}^{-1}\right)$, and to $20 \%$ calcite $(790$, 835,1020 , and $1430 \mathrm{~cm}^{-1}$ ).

Fig. 11 shows the IR-spectrum of the sample N5. 

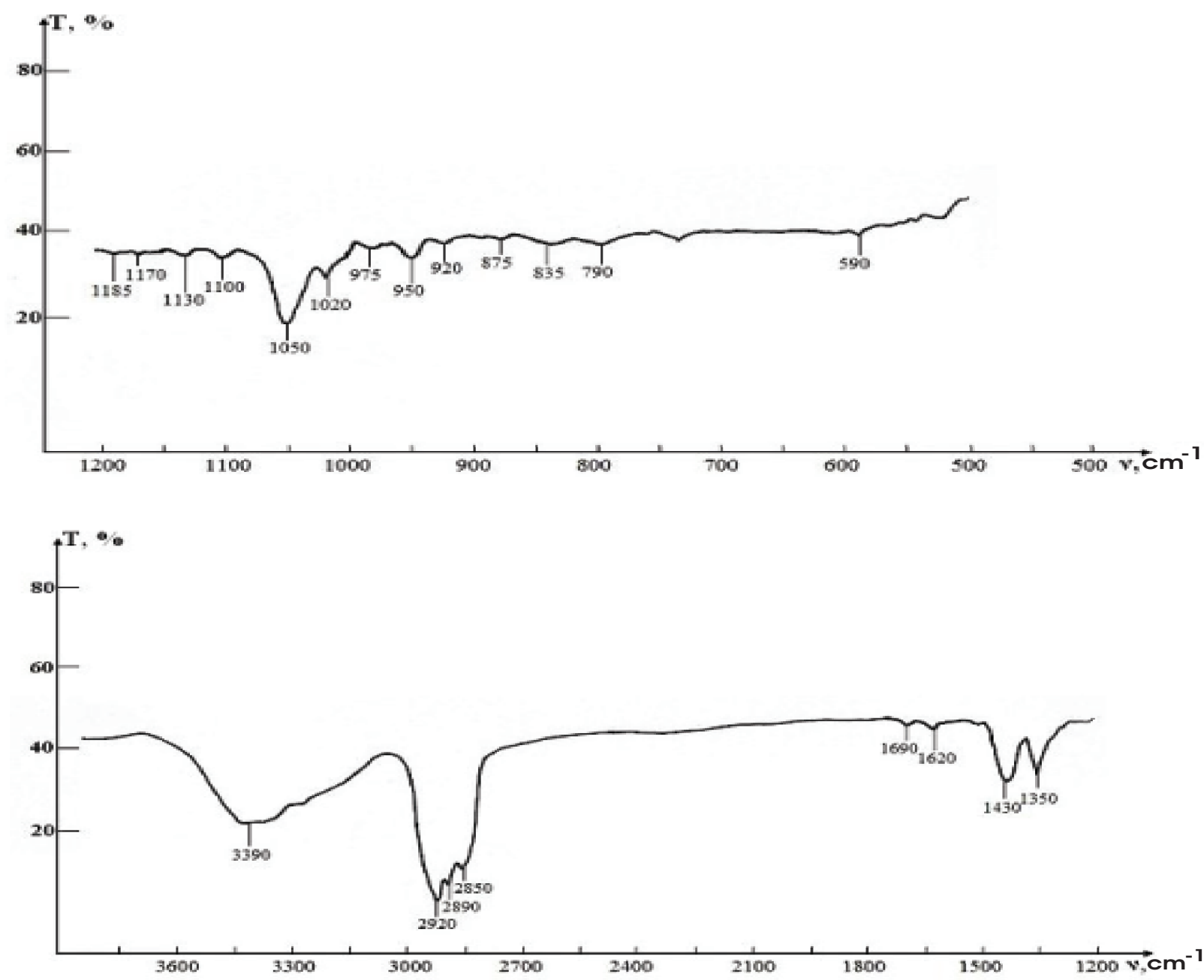

Fig.11. IR-absorption spectra the sample gallstones N5

4. CONCLUSIONS

The elemental content of gallstones in patients with hiatal hernia of the Kharkiv region was carried out by using gamma-activation analyses on LINAC NSC KIPT. The present study indicates that the elements content of gallstones had both similarity and difference in its composition. Therefore gallstones are formed by various mechanisms.

IR-spectroscopy is one of the effective methods for the determination of different chemical components of gallstones including bound water, and also for classification of gallstones and the etiology of formation of gallstones.

The gallstones are the multiphase samples. The main crystal phase of gallstones is cholesterol (40...70 volumetric \%), exception, the sample N1, in which the main phase is ARAGONITE (valence bond C-O, absorption bands $\left.1650,1770 \mathrm{~cm}^{-1}\right)(60 \%)$. The second main phase (samples N2-5) is amorphous bilirubin. The samples have modification crystal calcium carbonate (calcite, aragonite, vaterite). Some samples have a small quantity of calcium phosphates ( $15 \%)$. Thus patients in Kharkiv region have a mixed type of gallstones which consist of cholesterol and calcium carbonate bilirubinate.

\section{References}

1. Bulletin of the National Cancer Register of Ukraine. Kyiv, 2019, N20, 102 p.

2. B.J. Ha, S. Park. Classification of gallstones using Fourier-transform infrared spectroscopy and photography // Biomaterials Res. 2018, v.22, N18, p.1-8.

3. M. Ashok, T.R. Rautray, Pranaba K. Nayak, et al. Energy dispersive X-ray fluorescence analysis of gallstones // J. Radioanalytical and Nuclear Chemistry. 2003, v.257, N2, p.333-335.

4. T. Maki, T. Marsushio, N. Suzuki. Clarification of the nomenclature of pigment gallstones // World J. Gastroenterol. 2002, v.8, N3, p.413-420.

5. The infrared spectra of minerals/ Edited by V.C. Farmer. Mineralogical Society, Monograph 4, London, 1974, 359 p.

6. E. Larsen, G. Berman. Definition transparent mineral under a microscope. Moskow: Publishing house "Bowels", 1965, $464 \mathrm{p}$.

7. N.P. Dikiy, E.P. Bereznyak, S.N. Grigorov, et al. Variation of impurity element content, structure 
and phase composition of the teeth at inflammatory odontogenic diseases // PAST. Ser. "NPI". 2019, v.121, N3(71), p.47-52.

8. V. Valkovic. Analysis of biological material for trace elements using X-ray spectroscopy // $C R C$ Press Inc. Boca Ration. 1989, v.F1, p.17-22.
9. M.D. Stringer, D. Roger, R.D. Soloway et al. Calcium carbonate gallstones in children // J. Pediatric Surgery. 2007, v.42, p.1677-1382.

10. B. Sandstrom, B. Lonerdal. Zinc in Human Biology: Prompters and antagonists of zinc absorption. Springer-Verlag, Devon, UK, 1998, 464 p.

\title{
ЭЛЕМЕНТНЫЙ, ФАЗОВЫЙ И СТРУКТУРНЫЙ АНАЛИЗЫ ЖЕЛЧНЫХ КАМНЕЙ У БОЛЬНЫХ С ХИАТАЛЬНОЙ ГРЫЖЕЙ ХАРЬКОВСКОГО РЕГИОНА
}

\author{
Н.П. Дикий, Е.П. Березняк, В.В. Бойко, Е.П. Медведева, К.Ю. Пархоменко, \\ Т.А. Пархоменко, Ю.С. Ходырева
}

Гамма-активационный анализ на линейном ускорителе ХФТИ, ИФ-спектрометрия и кристаллооптические исследования использовались для анализа содержания элементов, фазового анализа и структурных особенностей различного органического и неорганического составов жёлчных камней пациентов в Харьковской области. Показано, что можно установить присутствие в жёлчных камнях таких соединений, как билирубин и его соли, фосфаты кальция, карбонат кальция и различных микроэлементов. В основном у пациентов Харьковской области содержатся жёлчные камни смешанного типа с комбинацией холестерина, билирубината карбоната кальция.

\section{ЕЛЕМЕНТНИЙ, ФАЗОВИЙ І СТРУКТУРНИЙ АНАЛІЗИ ЖОВЧНИХ КАМЕНІВ У ХВОРИХ $З$ ХІАТАЛЬНОЮ ГРИЖОЮ ХАРКІВСЬКОГО РЕГІОНУ}

\author{
М.П. Дикий, О.П. Березняк, В.В. Бойко, О.П. Медведєва, К.Ю. Пархоменко, \\ Т.А. Пархоменко, Ю.С. Ходирева
}

Гамма-активаційний аналіз на лінійному прискорювачі електронів ХФТІ, ІЧ-спектрометрія та кристалооптичні дослідження використовувались для аналізу вмісту елементів, фазового аналізу та структурних особливостей різного органічного і неорганічного складів жовчних каменів пацієнтів у Харківській області. Показано, що можливо встановити наявність у жовчних каменях таких сполук, як білірубін та його солі, фосфати кальцію, карбонат кальцію та різних міроелементів. В основному у пацієнтів Харківської області містяться жовчні камені змішаного типу з комбінацією холестерину, білірубінату карбонату кальцію. 